\title{
IMPACT OF PASSENGER GROWTH IN SOEKARNO-HATTA AIRPORT
}

\author{
Alviansyah Refaldi', Mohammad Emraldi², Wynd Rizaldy ${ }^{3}$ \\ 1. STMT Trisakti, 2. STMT Trisakti, 3. STMT Trisakti \\ $\bowtie$ Corresponding author: emraldimuhammad@gmail.com
}

\begin{abstract}
The purpose of passenger growth analysis is to predict what we'll do for the future. Some airports in the world have a long plan to use their airport with effective and efficient, but in this period, Indonesia has a significant increase of population. So, in developing country such as Indonesia, the country must have good politic and economic. It can be implemented and can be survived for a long time, the result is a lot of people have a good financial and economic in their life. To cover their want and need in aviation point of view, we must do preventive action like building up the new terminal to expand and accommodate the passenger or airport development. Even though we can predict and do action about passenger growth, we must improve our service and quality as airport management in all of the aspect. Airport management has also made airport master plan. This study case, we consider the airport terminal capacity, planning problem as a whole. We use Method Descriptive Research.

Keywords:Passenger Growth, Airport Management, Terminal, Capacity, Development.
\end{abstract}

\section{Introduction}

Indonesia is known as an archipelago country, which has more than 17,000 islands, air transport being as the main of transport to connect all of islands in Indonesian and become an important of economic movement.(Martono \& Marina, n.d.). Because population growth in Indonesia constantly increase, it also has passenger growth which use air transportation in Indonesia always increasing every year. Furthermore airlines for low cost budget easy to get and no longer have a luxury item.Air transport is basically growing rapidly, it gives the advantages that we can travel long distances and is the most sensible alternative when the time is demanding.(Adisasmita, 2012)

Soekarno-Hatta international airport as the main airport in Indonesia, is located in Jakarta as the capital city, it is the one of getting the impact of passenger growth. Where there is a turnover of international and domestic passengers greatly happen in this place. Currently, Soekarno-Hatta Airporthas already built terminal 3, ultimate to relocate passenger growth. 
With more demand of aircraft passengers and cargo transport using aircraft make Soekarno-Hatta airport develop both service and expansion area. But at the same time there are things consideredand reviewed by management of Soekarno-hatta airport in developing airport. There are some impacts from unbalanced demand of aircraft passenger to airport capacity. For example, in several airports the impact that can be felt is schedule changes and flight delays, even flight cancellation. Effect from not being ready becomes some elements at the airport that must be handled.In some seasons, like Eid AlFitr and holiday season in Indonesia, demand for aircraft transport at the time will greatly increase from the usual day, and many airlines provide extra flights(I. P. Ricardianto, Djajaputra, \& Martono, 2017). During that season it becomes a challenge for Soekarno-Hatta airport to give great quality for passengers, like level of efficiency and flight delays that can be well accepted by passengers. Thus the manager of Soekarno-Hatta airport needs to forecast against passengers growth even for the next five or ten years and he also knows the need for a lot of future investment in airport sector to meet service request which are continuously increasing.

The main purpose of our paper is to know impact of increaseing passengers in Soekarno-Hatta airport, and what things should be done by the airport management to deal withthe problem, especially in forecasting passenger growth for next five or ten years.

\section{Method}

\section{A Case Study Soekarno Hatta Airport}

A case study is a way to understand and know more detail about the problems that discusses expanding knowledge through previous discussions. The case study is a summary of the discussion document that was carried out intensively against the organization or certain symptoms to report and provide a critical assessment of the case(Seyanont, 2012). Soekarno Hatta International Airport (IATA Code : CGK) is airport hub or main airport which can handle all domestic \& international flight. The location of this airport is near Jakarta, especially side of west jakarta. It is owned and 
operated by Angkasa Pura II (AP II), which also operate most commercial airports in Indomesia.

Air transport has traditionally experienced higher to groweconomic industry than most other industries. Demand for air transport is closely linked with economic development; at the same time air transport is a driver for economy sector.(Purwanto, Rafi, Pongoh, \& Rifni, 2017). Passengers have accessedtheir destination to alternative modes of transportation, such as rail or road, to reach(Voltes-Dorta, Rodríguez-Déniz, \& Suau-Sanchez, 2017)

Figure 1. Passenger movement by Airport Council International

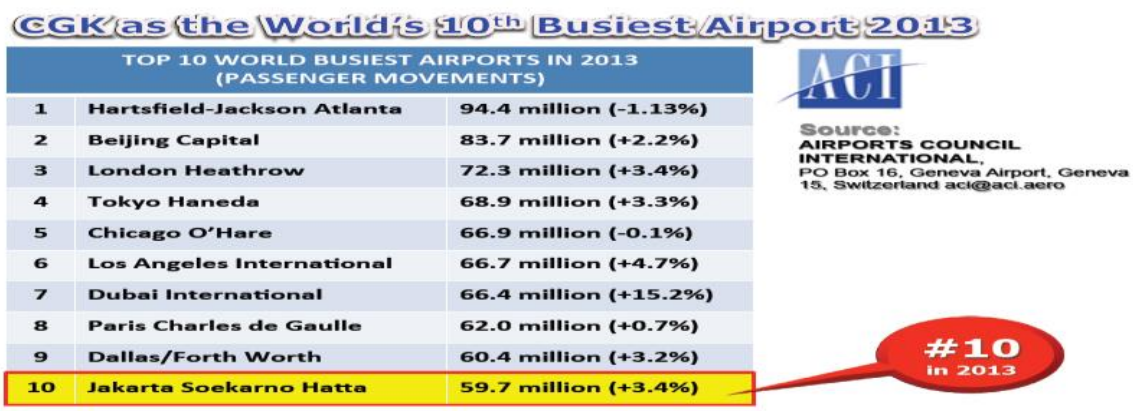

In December 2013, Soekarno Hatta Airport hadalready had 59,7 million passenger movements and the figure was a fact that Soekarno Hatta Airportwas becoming the world's $10^{\text {th }}$ busiest airport in 2013. Based on the grand design of Soekarno Hatta Airport,nowadays Soekarno - Hatta airport has 3 terminals(P. Ricardianto \& Rifni, n.d.). Soekarno-Hatta airport has wide and large terminal, but as time goes by the state's economy is improving, then it has an impact of passenger growth. Therefore, some passengers moved to Halim Perdana Kusuma Airport (IATA Code: HLP). On the other side, actually access to Soetta Airport is very limited. One of the problems happened is congestion on the highways to the airport.

\section{Descriptive Research}

Descriptive method is a method of researching the status of a group of people, an object, a set of conditions, a system of thought, or a class of events in the present. The purpose of this descriptive research is to make 
description, picture or painting in a systematic, factual and accurate about facts, properties and relationships among the phenomena will be investigated. According to Whitney (1960), descriptive method is a factfinding with proper interpretation.this data has collecting documents directly resource from AngkasaPura II authority(Kingdom, Simarmata, Keke, \& Panjaitan, 2016) Descriptive research studies some issues in society and procedures applied in society with certain situations, including in relationships, activities, attitudes, views, and ongoing processes and the effects of the phenomena. In descriptive method, the researcher just compared certain phenomena so that it was a comparative study. Sometimes researchers conducted a classification, as well as research on phenomena by setting a standard of certain norm so that many experts called this descriptive method with the name of normative survey (normative survey). This descriptive method also investigated position (status) phenomenon or factor and saw the relationship between one factor to the other factor. Therefore, descriptive method is also called status study (status study).

Descriptive methods also wanted to study the norms or standards, so that descriptive research was also called the normative survey. A descriptive method did a research of normative problem together with problem of status and also made comparisons between phenomena. Such studies were generally referred to as descriptive studies or studies. The time perspective to be reached in descriptive research, is the present time, or at least the time period is still affordably in the respondent's memory.

\section{Discussion and Result}

As already mentioned above, Soekarno Hatta airport needs to develop Terminal 4. Because of the rapid growth of passengers from year to year, even in 2013 Soekarno Hatta airport had become the 10th busiest airport in the world. Then what will happen for the next year if there is no development of airport Soetta? There are several things that should be noted in the development of airports, that is to meet the needs or to increase the 
passengers from year to year. Some of these things should be very noticed by the airport management, such as, planning system for airport, airport master plan, and etc.Airport planning is a complexity by the diversity of facilities and services which is necessary for the aircraft, passengers and cargo movement and the ground vehicles associated. An airport planning is also the evaluation of a compromise between conflicting features of the best plan for each individual facilities and providing the greatest degree of flexibility and expansibility for future development. This infrastructure has been plan by the airport master plan(Rafi \& Rifni, n.d.).

Figure 2. Integrated airport master plan approach

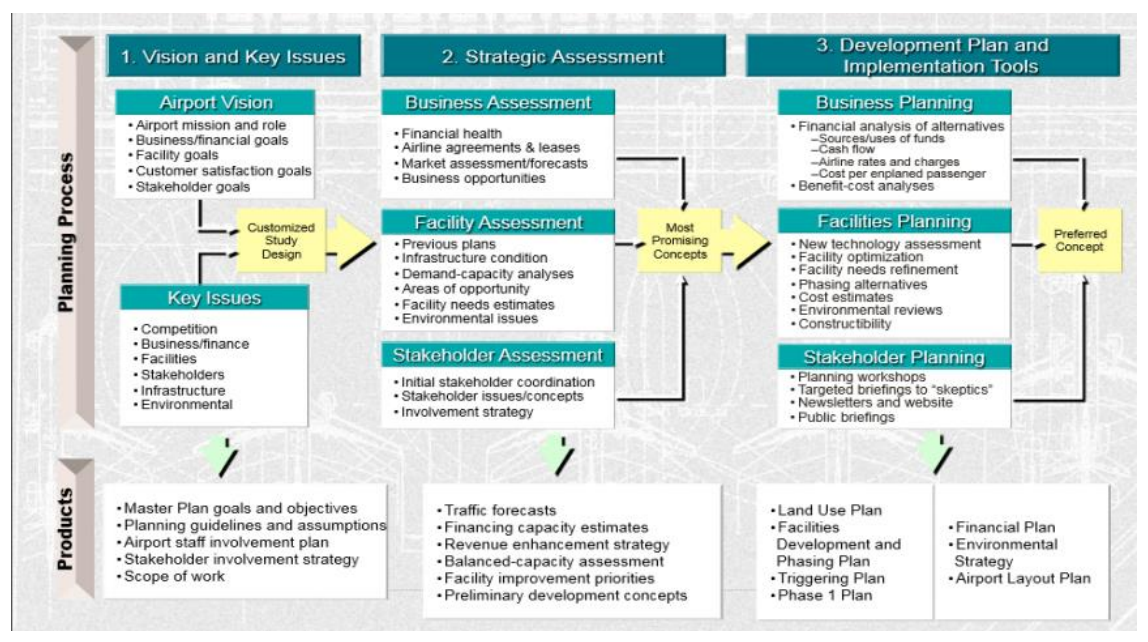

Figure 3. Airport master plan study schedule.

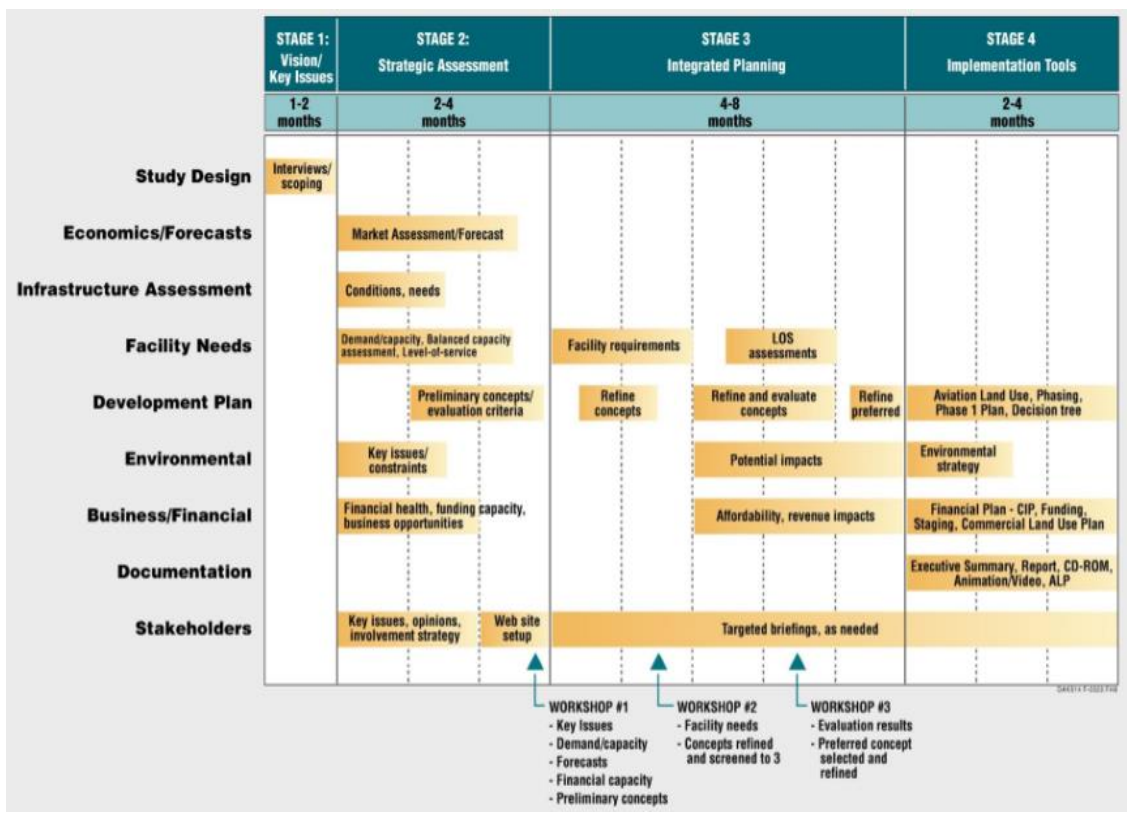


Furthermore, Here is an explanation about the master plan that was done by the airport developer of Soekarno hatta, namely Angkasa Pura II. In this discussion there are some things that are noticed by the developer. Soekarno Hatta International Airport started to operate in 1985, located 20 $\mathrm{km}$ from downtown of Jakarta city. That has 1800 hectare land areas, 2 parallel independent runaways, 3 passengers terminals (total capacity: 22 million pax / annum), 220,000 sqm of cargo area.Soekarno Hatta Airport is very large but still can not meet the needs of passenger density of the plane that continues to grow every year. Therefore, the management of Soekarno Hatta Airport has made master plan for 10 or even 20 years. Some of the Plans have already be developed.

Figure 4. Master plan CGK by Angkasa Pura II

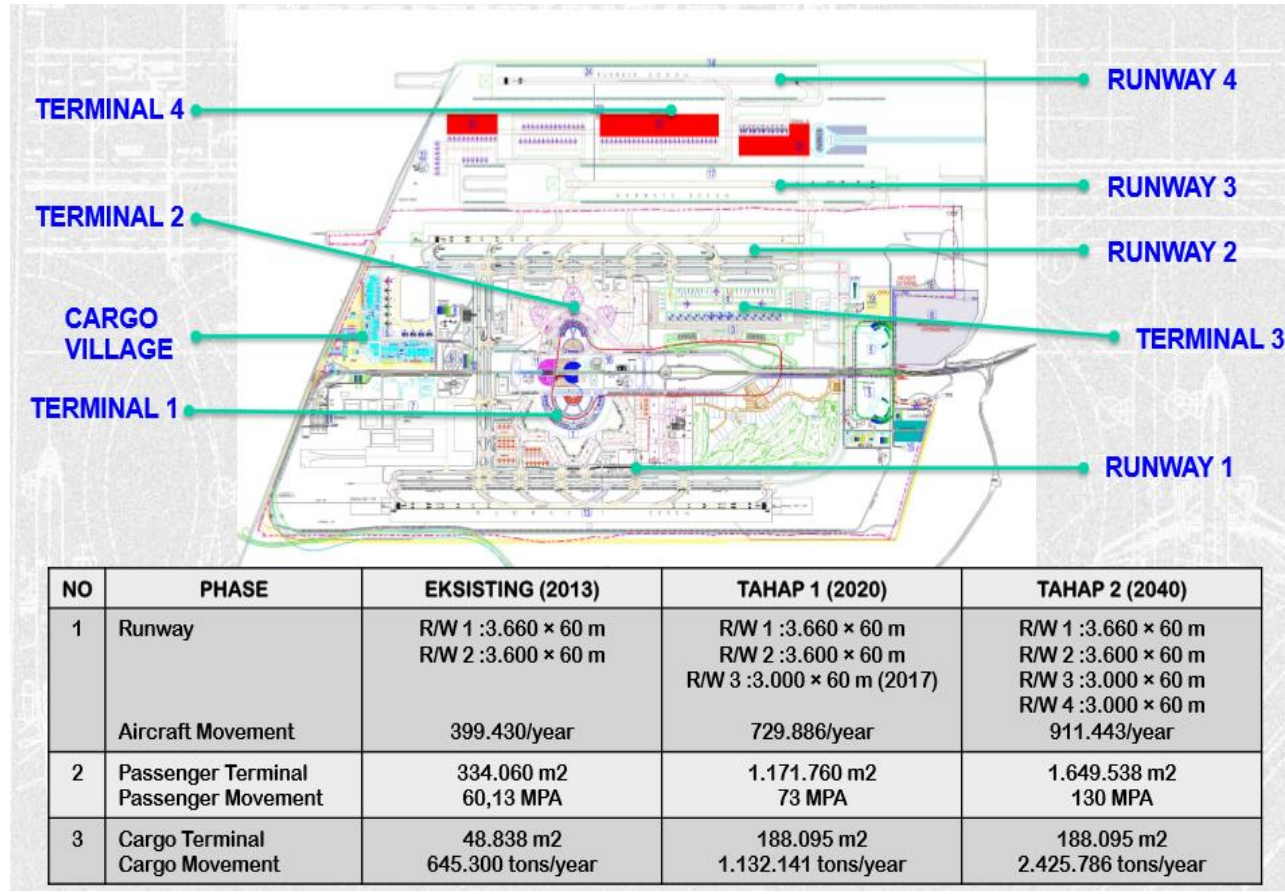

In making this master plan management, Soetta Airport has developedsome parts, for examplemaster plan 2013, where the managementdevelopers at the terminal at Soekarno Hatta are the creation of Terminal 3 ultimate. So there will be a shelter forthe rapid growth of passengers in Soekarno Hatta.The development's constraint of Soekarno Hatta airport is the difficulty of land acquisition by the manager. 
Conducting land acquisition is for building the construction of terminal 4 and runway 3 and runway 4 in the development stage for 2020 and the final stage in 2040. Someparts of the land that should be part of the SoekarnoHatta airport development project have been switched to become a development builder others. As it is now known that the area of Soetta Airport has become the place for the factory plant and also the residential housing, it will be very difficult for the managers to do the land acquisition, because it will be very highly cost to do. PT AngkasaPura must do acquisition to execute the master plan. In phase I; the land requirement of 198 hectare and the cleared land of 28 hectare, it is necessary to do the release again as much as 170 hectare. Next in phase II - stage 1; the need for land as much as 482 hectares and the cleared land is only 71 hectares, then it takes 411 hectare of land that must be released. For phase II - stage 2; the land needed 135 hectare and the land that is free is about 15 hectare, so it is needed to release 120 hectare again. The total of all phase I and phase II in needing of land expansion of 815 hectare, whereas that has been released the new 114 hectare then need to be free as much as 701 hectare of land again. The Results of this study we speculate that in the next 5 years Soekarno Hatta Airport Terminal 1, Terminal 2, Terminal 3 Ultimate will overcapacity. That's why the airport should prepare Terminal 4 to be a solution for the problem of passenger growth. If it is not immediately conducted, then the passengers can be displaced,they can't even get the tickets to get to their respective destinations.

Figure 5. Aerotropolis schematic by Dr. John D. Kasarda

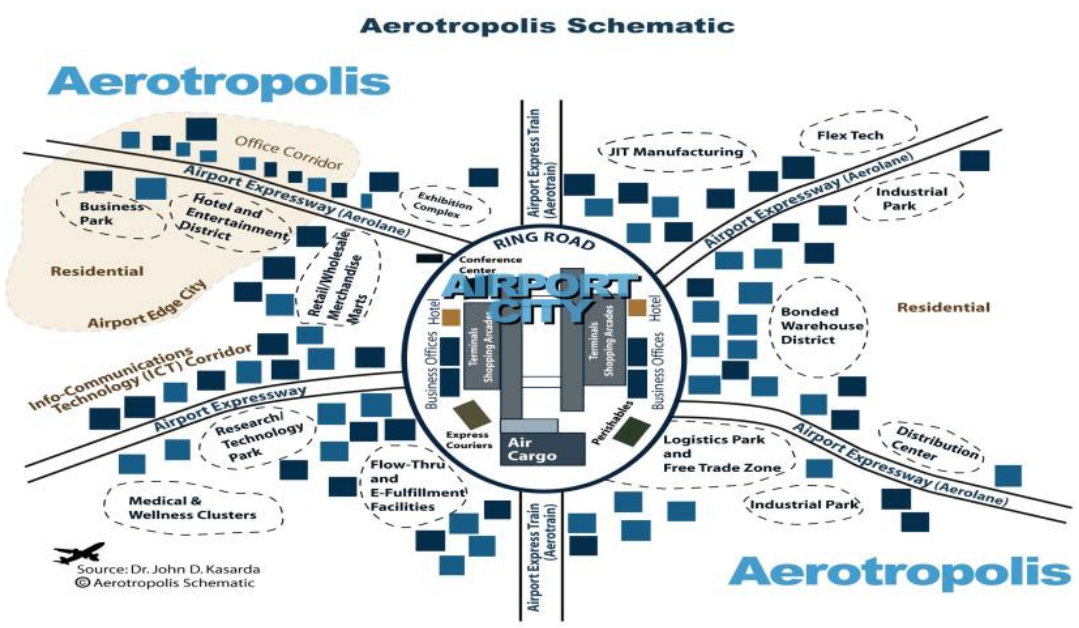


Aerotropolis schematic or concept is very important to implement in Soekarno-Hatta airport, because with increasing or the growth of passenger it can get the multiplier effect for airport infrastructure development, related business growth, airport surronding area economic development, and positive impact on national economy. To implement this concept, the main or local government must to realize about to save the land for aerotropolis concept. In Indonesia, espacially in Soekarno-Hatta airport there is not available an empty land to implement this concept, at the end the airport management must to work together and think together with central government and local government. If this concept can implement in Soekarno-Hatta airport, the impact is very big for local communities and local economic development.

\section{Conclusion}

So, the main result of this study is to agree on the hypothesis taken from dicussion by looking at the facts in the field. That with the increasing growth of passengers, it will affect the capacity of each terminal in the area of Soekarno Hatta Airport. On the other hand, there is almost an overcapacity. With the emergence of this research, the problem can be seen clearly and completely. It is not impossible that the Indonesian government should be ready to build Terminal 4 , because in building the terminal the government must have a medium term plan that is 5 years \& long-term plan that is 10 years or more. For the future, central government must to keep the land for aerotropolis schematic in Soekarno-Hatta airport. It concept is very brilliant idea for Soekarno-Hatta airport, some country in the world precisely viewed as center strategic activities integrated. The airport is associated with various facilities and non-aeronautical services such as hotel, entertainment center, center shopping, complex exhibitions and conferences, centers trade, office buildings, logistics room, and free trade zone. 


\section{References}

Adisasmita, S. A. (2012). Level of service analysis and airport terminal development (Case Study: Soekarno-Hatta International Airport , Indonesia). International Journal of Engineering \& Technology, 12.2(April), 48-61.

Kingdom, U., Simarmata, J., Keke, Y., \& Panjaitan, F. (2016). THE AIRLINE CUSTOMER ' $\mathrm{S}$ BUYING DECISION THROUGH ONLINE TRAVEL AGENT: A CASE STUDY OF THE PASSENGERS, $I V(3)$, 335-349.

Martono, K., \& Marina, S. (n.d.). Domestic Air Transport Regulations in Indonesia, 3(1), 1-19.

Purwanto, B., Rafi, S., Pongoh, H. A., \& Rifni, M. (2017). STRATEGIC DECISION IN AIRPORT RELOCATION : A CASE STUDY FROM KUALANAMU , INDONESIA, 6(July), 69-76.

Rafi, S., \& Rifni, M. (n.d.). SOFT SYSTEMS METHODOLOGY PADA PENGEMBANGAN BANDAR UDARA PROVINSI SULAWESI BARAT SOFT SYSTEM METHODOLOGY-BASED ON DEVELOPMENT OF AIRPORT OF WEST SULAWESI, 4(2), 159176.

Ricardianto, I. P., Djajaputra, D. G., \& Martono, P. D. (2017). Air Transport and Tourism in Indonesia. IOSR Journal of Applied Chemistry, 10(5), 01-19. https://doi.org/10.9790/5736-1005010119

Ricardianto, P., \& Rifni, M. (n.d.). Aerodrome Safety for Manouvering Area in Soekarno-Hatta International Airport Cengkareng, 2(3).

Seyanont, A. (2012). Passengers' perspective toward airport service quality at Suvarnabhumi International Airport. Journal of Society for Transportation and Traffic Studies, 3(3), 32-41.

Voltes-Dorta, A., Rodríguez-Déniz, H., \& Suau-Sanchez, P. (2017). Passenger recovery after an airport closure at tourist destinations: A case study of Palma de Mallorca airport. Tourism Management, 59(November 2015), 449-466. https://doi.org/10.1016/j.tourman.2016.09.001 